\title{
Laatutyön arvioinnista ammattikorkeakouluissa
}

Satu Pehu-Voima

\author{
Laatutyö koko ammattikorkeakoulun \\ organisaation kattavana toimintana hakee vielä \\ muotoaan. Siksi on luonnollista, että laatutyöhön \\ itseensä kohdistuva arviointi on alkutaipaleellaan. \\ Laatuideologian soveltaminen \\ koulutusorganisaatioissa ei ole kuitenkaan \\ saavuttanut kaikkien hyväksyntää. Monien \\ mielestä koulun kehittämisessä pitäisi lähteä \\ liikkeelle syvällisemmän ymmärtämisen avulla.
}

Ammattikorkeakoulut ovat jo nimensä mukaisesti kiinteässä yhteydessä työelämään. Erityisesti ammattikorkeakoulujen teknillisillä ja liiketalouden osastoilla on yhteistoimintaa yritysten kanssa, joissa erilaiset laadunvarmistus- ja kehittämisohjelmat ovat arkipäivää. Ammattikorkeakoulut ovatkin lyhyessä ajassa omaksuneet laatuajattelun ja rakentaneet omia laatuohjelmiaan (Virtanen, 1997). Ensimmäisen laatuohjelmaarvioinnin mukaan (Pilot Audit of Quality Work, 1998) laatutyö ei kosketa kaikkia oppilaitosten kannalta keskeisiä toimintoja, eivätkä kaikki opettajat miellä sitä oman työnsä kehittämisvälineeksi. Yritysmaailmasta peräisin oleva laatuajattelu näyttää kuitenkin asettuneen ammattikorkeakouluihin selvästi tukevammin kuin yleissivistävään perusopetukseen tai yliopistokoulutukseen (Syrjäläinen, 1997, Liuhanen, $1997^{1}$ ). Laatutyöllä on ammattikorkeakouluissa merkitystä myös muutosten läpiviemisessä, joita siirtyminen monialaisiin, yhtenäisinä toimiviin korkeakouluihin vaatii.

Ammattikorkeakoulujärjestelmän luomisen yhtenä tavoitteena on ollut ammatillisen koulutuksen hallinnon hajauttaminen ja tulosvastuun siirtäminen oppilaitoksille (Higher Education Policy in Finland, 1998). Oppilaitosten omien arviointi- ja kehittämisjärjestelmien ajatellaan edistävän vastuun siirtymistä. Ulkopuoliset arvioinnitkaan eivät enää keskity pelkästään opetuksen tai sen tukitoimien suoraan laadun tarkasteluun, vaan arvioinnin kohteena voivat olla myös laadunvarmistus, -arviointi- ja -kehittämisjärjestelmät, joita tässä yhteydessä kutsutaan laatutyöksi. 
Tässä artikkelissa esitellään ammattikorkeakoulujen laatutyön arviointiprojektia, sen tuloksia ja hyödyllisyyttä oppilaitosten kehittämisessä. Pilottiarvioinnin kokemusten perusteella tarkastellaan myös laatutyön arviointimenetelmän vahvuuksia ja heikkouksia.

\section{AKKREDITOINTI, LAADUN ARVIOINTI JA LAATUTYÖN ARVIOINTI}

Kolme yleisimmin käytössä olevaa koulutuksen laadun ulkoista arviointi- ja sääntelymenetelmää ovat akkreditointi, koulutuksen laadun arviointi ja arviointi- ja kehittämisjärjestelmien arviointi (eli laatutyön arviointi). Kaikkiin näihin kolmeen arviointimenetelmään sisältyy yleensä itsearviointi ja ulkoinen arviointi, mutta arvioinnin suorittajataho, kohde ja tulosten julkisuusaste vaihtelevat (Dill, 1998).

A KKREDITOINNISSA, esimerkiksi toimilupa-arvioinnissa määritellään onko oppilaitos, sen osasto tai ohjelma saavuttanut ennalta asetetut kynnyskriteerit. Esimerkiksi ammattikorkeakoulujen toimilupa-arvioinnissa tarkastetaan, täyttääkö oppilaitos korkeakoululle asetetut taso- ja laatuvaatimukset. Siinä keskitytään korkeakoulun toiminta-ajatukseen, resursseihin ja menettelytapoihin. Arvioinnin tulokset julkaistaan aina. Dillin (1998) mukaan kaikkia yksityiskohtia ei kuitenkaan ole syytä tuoda julki, varsinkin jos niiden julkistamisesta aiheutuu haittaa myöhemmille arvioinneille tai kehittämistoimille. Kun palvelujen, esimerkiksi koulutuksen, tarjonta perustuu asiakkaiden vapaaehtoiseen palvelujen käyttöön, voidaan akkreditointia hyödyntää organisaation uskottavuuden, statuksen ja julkiskuvan kohottamisessa (Raivola, 1998).

$\mathrm{K}$ OULUTUKSEN LAADUN ARVIOINNISSA (quality assessment) kiinnitetään huomiota toiminnan laatuun koulutusohjelmatasolla. Kohteena voi olla sekä oppiminen, opettaminen että tutkimus. Laatutasoa arvioidaan suhteessa koulutukselle asetettuihin tavoitteisiin. Tulokset voidaan ilmaista arvosteluasteikolla. Koska tällaisen arvi-

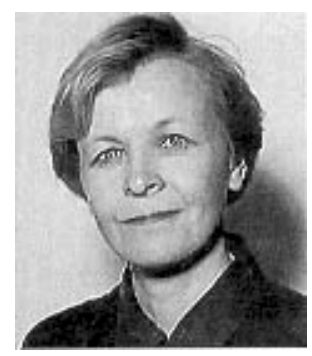

Satu Pehu-Voima

oinnin ensisijainen tarkoitus on tulosvastuuseen liittyvä kontrolli, tulokset yleensä julkaistaan siinä muodossa, että ohjelmien välinen vertailu mahdollistuu. (Dill, 1998)

$\mathrm{L}$ AATUTYÖN ARVIOINNISSA (academic audit) ei tarkastella korkeakoulutuksen laatua sinänsä, vaan opetusta koskevien laadunvarmistusjärjestelmien tehokkuutta ja luotettavuutta. Toisin kuin koulutuksen laadun arvioinnissa laatutyön arvioinnissa kiinnitetään huomiota niihin seikkoihin, joita oppilaitokselta kokonaisuudessaan vaaditaan korkeatasoisen koulutuksen tuottamiseen. Lähtökohtana on se, että korkeakoulut arvioivat itse säännöllisesti opetusohjelmiaan, opetustaan ja myöntämiään tutkintoja. Ulkopuolisen arvioinnin tehtävänä on arvioida, kuinka hyvin järjestelmä on suunniteltu, ja pystyykö henkilöstö puolustamaan tekemiään valintoja. Tässä arvioinnissa ei siis tarvitse etukäteen määritellä tulosmittareita tai standardeja. Sen sijaan halutaan saada selville, onko oppilaitos määritellyt ne ja vaikuttavatko heidän valintansa järkevältä toiminta-ajatuksen valossa. (Dill, 1998)

Laatutyön arvioinnissa tarkastellaan organisatoristen toimenpiteiden lisäksi myös asenteita, jotka molemmat sisältyvät koulutuksen laadun käsitteeseen (Squires, 1998). Opettajia, opiskelijoita ja muuta henkilöstöä haastattelemalla selvitetään, millaisia menettelyjä ja toimenpiteitä on olemassa mutta myös sitä, pidetäänkö arviointi- ja kehittämistyötä tärkeänä ja toteutuuko se arkipäivän toiminnassa. Silénin (1998) mukaan organisaatioon voi syntyä laatukulttuuri silloin, kun siinä ymmärretään laaja-alaisen ja moniulotteisen laadun käsite ja kun toiminta orga- 
nisoidaan tähän ymmärrykseen pohjautuen. Arvioinnissa tutkitaan, onko tällaista kulttuuria korkeakoulussa olemassa tai onko sen syntymiselle edellytyksiä tai esteitä. Laatutyön arviointimenetelmässä korostuu oppilaitoksen kehittämisnäkökulma. Siksi tuloksia on vaikea verrata oppilaitosten välillä, vaikka tulokset yleensä julkaistaan (Dill, 1998).

\section{LAATUTYÖN ARVIOINTIPROJEKTI}

\section{Arvioinnin toteuttaminen}

Korkeakoulujen arviointineuvosto käynnisti keväällä 1997 pilottihankkeen, jonka tarkoituksena on ammattikorkeakoulujen laatujärjestelmien arvioiminen ja niiden kehittäminen. Tavoitteena on antaa palautetta laatutyön toteutuksesta kullekin oppilaitokselle ja myös jakaa tietoa hyvistä käytänteistä oppilaitosten välillä. Pilottihankkeessa olivat mukana Kajaanin, Turun, Lahden ja Hämeen vakinaiset ammattikorkeakoulut. Projektia ohjaa johtoryhmä puheenjohtajanaan rehtori Tapio Varmola Seinäjoen ammattikorkeakoulusta (Pilot Audit of Quality Work in Polytechnics, 1998).

$\mathrm{K}$ oska ammattikorkeakoulujen dokumentoidut laatuohjelmat ja menettelytapaohjeistot ovat vasta kehittymässä, pilottivaiheessa ei ollut perusteltua rajoittaa arviointia niihin. Haastatteluissa käsiteltiin myös sitä, miten korkeakoulut olivat rajanneet ohjelmiensa sisällön, toisin sanoen, mitkä ovat koulutuksen laadun kannalta keskeisiä asioita ja miten hyvä laatu näissä ilmenee.

Toisin kuin esimerkiksi perusopetussektorilla toteutettavassa Oppi ja laatu -hankkeessa (1997), ammattikorkeakoulujen laatutyön arvioinnissa ei ole kehitetty arvioinnin kohteita tarkasti kuvaavaa mallia, vaan on ajateltu, että arvioinnit kattavat laatutyön siltä osin kuin se kussakin oppilaitoksessa on määritelty. Koska useampia oppilaitoksia osallistuu arviointiin samassa aikataulussa, on yhteistyötä tehty itsearviointiraporttien rakenteen ja alkuvaiheessa myös arvioinnin kohteiden määrittelyssä. Ensimmäisellä kierroksella neljästä korkeakoulusta koostuva työryhmä määritteli arvioinnin kohteet seuraavasti (Arviointityöryhmän esitys, 1997):

A) Laatutyön liittyminen ammattikorkeakoulun strategisiin tavoitteisiin ja laatutyön strategia

1 Laatutyön ja arvioinnin liittyminen strategiaprosessiin ja vuotuisen toiminnan suunnitteluun?

1 Laatutyön ja arvioinnin periaatteet ja lähestymistavat?

1 Arvioinnin ja kehittämisen resurssointi?

1 Laatutyön liittyminen ammattikorkeakoulun kehitysvaiheeseen?

\section{B) Johtajuus}

1 Johdon sitoutuminen laatutyöhön?

1 Miten laatutyö tukee johtamista?

1 Arvioinnin ja palautteen hyödyntäminen ja asema johtamisessa?

1 Miten johto edistää tiimityötä?

\section{C) Tavoitteiden asettaminen}

1 Miten tavoitteet tukevat toiminta-ajatuksen saavuttamista?

$1 \quad$ Asiakkaiden $^{2}$ ja sidosryhmien tunnistaminen?

1 Osallistuvatko asiakkaat ja sidosryhmät tavoitteiden asettamiseen?

1 Kuinka laajana yhteistyö työelämän ja muiden sidosryhmien kanssa toteutuu?

\section{D) Työyhteisö}

1 Laatutyöhön sitoutuminen, osallistuminen ja kyvykkyys?

1 Laatutyön organisointi ja asema?

1 Laatutyön kohteiden mielekkyys ja priorisointi eri tasojen ja henkilöstöryhmien sekä opiskelijoiden kannalta?

1 Tiimityöskentelyn toteutuminen/onnistuminen?

\section{E) Prosessien hallinta}

1 Prosessien (ydin- ja tukiprosessit) tunnistus ja määrittely?

1 Vastuunjaon selkeys (prosessien omistajat)?

1 Määriteltyjen prosessien kehittyminen?

1 Käytetäänkö sisäistä ja/tai ulkoista vertailua parhaisiin käytänteisiin? 
1 Menettelyiden vaikuttavuus prosessien tuotoksiin ja prosessien kehittämiseen?

F) Arviointi- ja seurantajärjestelmä

1 Arvioinnin informaatiojärjestelmät?

1 Arvioinnin kohteiden tarkoituksenmukaisuus ja riittävyys?

1 Palautteen käsittely ja arviointisystematiikka?

1 Palautteen käyttö laatutyössä?

1 Toiminnan vaikuttavuuden arviointi?

1 Laatutyön vaikuttavuuden arviointi?

L aatutyön arvioinnissa ei pitäydytty ammattikorkeakoulun johtamisen tasolla, vaan haluttiin ulottaa arviointi opettajan, henkilökunnan ja opiskelijoiden toimintaan ja heidän yhteyksiinsä keskeisiin sidosryhmiin. Kokemusten mukaan arvioinnista saadaan suurin hyöty silloin, kun siihen osallistutaan laajasti eri organisaation tasoilla. Havaittiin, että itsearviointi voi olla osa laatutyötä ja laatuajatteluun perehdyttämistä. Laatutyön avulla voidaan tehokkaasti viestiä organisaation tavoitteita, saada opettajat, henkilökunta ja opiskelijat osallistumaan, parantaa tiedonkulkua organisaatiossa alhaalta ylöspäin, työskennellä tiimeissä ja lisätä vuorovaikutusta yli osasto- ja koulutusohjelmarajojen.

Laatutyötä arvioitiin seuraavilla tasoilla:

1 ammattikorkeakoulun laatutyö kokonaisuutena

1 koulutusohjelmissa tapahtuva laatutyö

1 laatuohjelmaan kuuluvat prosessit ja/tai painopistealueet. Päähuomio oppimis-, opetus-, ja koulutusprosesseissa.

$\mathrm{U}$ lkoiset arviointiryhmät tutustuivat itsearviointiraportteihin ja suorittivat kaksipäiväiset arviointivierailut, jonka aikana he tapasivat keskimäärin 11 johto-, opettaja-, henkilöstö- ja oppilasryhmää kussakin ammattikorkeakoulussa. Arviointiryhmien puheenjohtajina toimivat suunnittelija Paul Almefelt Ruotsin korkeakoulujen arviointineuvostosta ja professori Lee Harvey Birminghamista (University of Central England) ja jäseninä projektipäällikkö Paula Pelttari Stakesista, kehittämispäällikkö Rolf Hultin, Rautaruukista ja laatupäällikkö Juhani Mansikka- mäki Siemens Osakeyhtiöstä. Työ- ja raportointikielenä käytettiin englantia.

\section{Tuloksia}

Ulkoinen arviointiryhmä havaitsi ammattikorkeakoulujen yhteiseksi piirteeksi sen, että opettajat ja opiskelijat arvostavat oppilaitoksiaan ja ovat innostuneita ammattikorkeakoulun tarjoamista uusista mahdollisuuksista. Koska ammattikorkeakoulujen toiminta yhtenäisinä ja monialaisina oppilaitoksina on nuorta, niissä etsitään nyt ammattikorkeakouluidentiteettiä ja keinoja hyödyntää monialaisuuden antamia mahdollisuuksia. Koko oppilaitoksen laajuinen laatutyö vaatii kuitenkin selvää näkemystä yhteisistä tavoitteista, jotka ovat ammattikorkeakouluissa vasta selkiytymässä.

$A_{\text {opettamisen keskeisinä prosesseinaan. }}^{\text {mmattikorkeakoulut näkevät oppimisen ja }}$ Keskustelu ammattikorkeakoulutuksen omista pedagogista lähtökohdista on alussa mutta näyttää siltä, että oppilaitoksissa tunnistetaan tämän keskustelun tärkeys ja sille etsitään uusia, koulutusalojen rajat ylittäviä muotoja. Opiskelija halutaan ottaa toiminnan keskipisteeksi, ja oppimista pidetään tärkeämpänä kuin opettamista. Näiden periaatteiden saattaminen käytännön toiminnaksi vaatii kuitenkin vielä työtä. Esimerkiksi opiskelijapalautteen keruu ja käyttö suunnittelussa, toteutuksessa ja arvioinnissa sekä opiskelijan informoiminen palautteen vaikuttavuudesta eli sen aiheuttamista korjaavista toimenpiteistä ei toteudu systemaattisesti.

Muutamat ammattikorkeakoulujen tekniset ja liiketalouden osastot ovat hankkineet ISO- standardien mukaisen sertifioinnin ohjelmilleen ja Suomen laatupalkinnon arviointiperusteet ovat lähtökohtana monien ammattikorkeakoulujen laatutyössä. Arvioinnissa tuli esiin, että nämä selkeät mallit eivät ole kaikkien mielestä paras mahdollinen perusta laatutyölle opetusyhteisössä. Osa haastatelluista esitti, että yritysmaailman mallit saattavat etäännyttää opettajat ja muut henkilöstön opetuksen ja oppimisen kannalta keskeisistä asioista. Laatupalkintomallissa käytetään 
käsitteitä, jotka eivät ole sovellettavissa suoraan opetusyhteisössä. On vaarana, että toimintatapoja yritetään muuttaa pinnallisesti vastaamaan yritysmaailman käytänteitä ja käsitteet, kuten johtajuus ja asiakkuus saavat opetusyhteisölle vieraan merkityksen. Tuli myös esiin, että kaikki eivät mieltäneet "tavallisia" arviointi- ja kehittämistoimenpiteitä laatutyöksi. Laatutyö ei siten ollut tullut osaksi jokapäiväistä työtä.

\section{MITÄ OPITTIIN}

Koska laatutyö systemaattisena, koko organisaation kattavana toimintana hakee vasta muotoaan ammattikorkeakouluissa, on luonnollista, että siihen kohdistuva arviointi on alkutaipaleellaan. Tästä huolimatta laatutyön arviointiprojektin ensimmäinen kierros osoitti, että laatuajattelun peruselementit - opiskelijalähtöisyys, laadun välineellisyys, jatkuvan parantamisen ja muutoksen tärkeys sekä johtajuuden ja henkilöstön osallistumisen tärkeys - toimivat hyvänä arvioinnin lähtökohtana. Nämä keskeiset käsitteet sisäistäneet ja niitä joustavasti soveltavat arvioijat saattoivat nopeasti löytää yhteisen perustan ja kielen arvioinnille. Lisäksi he osasivat kiinnittää huomionsa asioihin, jotka ammattikorkeakoulujen edustajien mielestä olivat keskeisiä heidän toiminnassaan.

$\mathrm{L}$ aatutyön arvioinnin hyöty oppilaitoksen kehittämistyössä heikkenee, jos arvioinnille asetetaan tavoitteita, joita se ei voi täyttää. Laatutyön arvioinnissa ei tarkastella esimerkiksi opetussuunnitelman sisällön tai rakenteen mielekkyyttä. Koska esimerkiksi opetusta, hallintoa tai kansainvälistä toimintaa ei suoraan arvioida, ei niistä voida arviointiraportissa esittää tuloksia kuin epäsuorasti: esimerkiksi, että kansainvälisestä toiminnasta saatuja kokemuksia ei olla hyväksi käytetty opetuksen suunnittelussa.

Ammattikorkeakoulujen antamassa palautteessa tuli esiin, että sekä itsearviointi että ulkoinen arviointi prosesseina olivat yhtä tärkeitä kuin arvioinnin tulokset. Mitä laajemmin ja syvemmin organisaatio osallistui arviointiin, sitä suurempi hyöty siitä oli.
Arviointiprosessi näytti toimivan välineenä laatu- ja kehittämisajattelun istuttamisessa oppilaitoksiin. Arviointi pakotti työyhteisön kokeilemaan yhteistyömuotoja ja keskustelemaan heille tärkeistä asioista uusissa kokoonpanoissa ja uusilla tavoilla. Jotkut opettajat kertoivat, että yksilön ongelmista tuli yhteisön ongelmia arvioinnin kuluessa. Toisin sanoen, syntyi tehokkaita kehittämistyömuotoja. Joidenkin ammattikorkeakoulujen johtohenkilöt pitivät arviointia tehokkaana tapana viestiä ja edistää oppilaitoksen tavoitteiden saavuttamista.

$\mathrm{K}$ oska systemaattista laatutyötä ja sen arviointia on tehty vasta vähän aikaa, ei arvioinnissa ole voitu tarkastella arviointi- ja kehittämistoiminnan vaikuttavuutta. Pitkäaikaisia seurantalukuja tai tilastoja ei ole käytettävissä. Arvioinnissa ei myöskään pyritty tekemään tarkastusta itsearvioinnissa esitettyjen menettelyjen todellisen soveltamisen laajuudesta. Laatutyön saadessa vakiintuneita muotoja, voidaan arviointia kehittää näiltä osin.

\section{ARVIOINNIN KOHDENTAMINEN}

Laatuideologian soveltaminen koulutusorganisaatioissa ei ole saavuttanut kaikkien hyväksyntää. Monien mielestä koulun kehittämisessä pitäisi lähteä liikkeelle syvällisemmän ymmärryksen avulla. Oppilaitoksen kehittämistä tulisi suunnitella ja viedä eteenpäin vain sellaisen tiedon perusteella, joka nojaa koulutuksen ja opetuksen arkimaailman tapahtumiin, dynamiikkaan ja todellisuuteen. Oppilaitoksen hallinto ja toiminta organisaationa on hyvin erilainen ilmiö kuin oppiminen ja siihen pyrkivä opettajan työ opiskelijan kanssa. Laatutyön käsitteet näyttävätkin tavoittavan oppilaitoksen toiminnan organisaation tasolla melko hyvin, mutta niissä on rajoitetusti aineksia kuvaamaan opiskelijan ja opettajan välistä vuorovaikutusta. (Syrjäläinen, 1997)

Esimerkiksi Isossa-Britanniassa, missä akateemista laadunvarmistusta ja -kehittämistä arvioidaan laajamittaisesti, näyttää siltä, että laatutyön arvi- 
oinnin vaikutus itse oppimisprosessiin ainetasolla on verrattain vähäistä. Siellä koulutusohjelmien laadun arvioinnilla (assessment) on havaittu olevan suurempi vaikutus erityisesti opetussuunnitelmiin kuin laatutyön arvioinnilla. Palaute osoittaa laatutyön arvioinnin vaikuttavan enemmän laadunvarmistusjärjestelmään koko yliopiston tasolla (Dill, 1998). Myös Suomen ammattikorkeakouluja arvioitaessa havaittiin, että systemaattinen laatutyö oli monessa oppilaitoksessa aloitettu hallintotoiminnan kehittämisestä. Siksi korkeakoulujen keskushallinnon henkilöstö ymmärsi laatutyön perusteita parhaiten. Keskushallinto on myös vastuussa dokumentaation kehittämisestä, joka Dillin (1998) mukaan saa usein liikaa huomioita laatuohjelmissa.

Opetusyhteisöjen kannalta keskeisille laadun käsitteille ja opettajan roolille on lähdetty etsimään tarkennuksia ja uusia määritelmiä. Massy (1997) esittää, että koulutusjärjestelmässä laadusta olisi vastuussa opetushenkilöstö kollektiivisesti. Vertaispaine on hänen mukaansa paras ja ehkä ainoa tapa valvoa yksilöiden suoritusta asiantuntijaorganisaatiossa. Pedagogisen työn johtaminen halutaan nähdä vähintään yhtä tärkeänä kuin oppilaitoksen muu hallinto.

Nämä näkökulmat ovat ohjanneet joitakin korkeakoulutuksen laatutyön arviointeja. Niissä arviointi on rajattu koskemaan opettamisen ja oppimisen kannalta keskeisiä prosesseja. Esimerkiksi Hongkongissa korkeakoulujärjestelmässä toteutettu laatutyön arviointi, jonka esikuvat ovat Englannista ja Uudesta Seelannista, keskittyy seuraaviin teemoihin (Massy, 1997):

\section{Opetussuunnitelmatyö:}

Millaisista prosesseista opetussuunnitelman teko ja sen uudistaminen koostuu ?

\section{Pedagoginen suunnittelu:}

Millaisia prosesseja liittyy opetusmenetelmällisten ratkaisujen tekemiseen ja niiden kehittämiseen ?

\section{Opetuksen toteutuksen laatu:}

Kuinka hyvin opetushenkilöstö hoitaa työnsä?

\section{Tulosten arviointi:}

Kuinka opettajat, osastot ja korkeakoulut seuraavat ja mittaavat tuloksia ja liittävät tulosten mittaamisen opettamisen ja oppimisen kehittämistyöhön?

\section{Resurssien jako:}

Ovatko tarvittavat henkilöstö, tekniset ja taloudelliset resurssit käytettävissä laadun kannalta keskeisissä kohteissa silloin kun tarvitaan?

Hong Kongin korkeakoulujen laatutyön arviointia ei ohjannut etukäteen määritelty käsitys tai malli siitä, millainen on hyvä laadunvarmistusja kehittämisohjelma. Arviointien aikana kuitenkin hahmottui, että seuraavat osa-alueet ovat yleensä mukana onnistuneessa opetuksen ja oppimisen laadun kehittämistyössä:

Laatuohjelman viitekehys: toiminta-ajatus ja toimintapoliittiset näkemykset laatutyöstä organisaation eri tasoilla. Tämä viitekehys toimii yksilöiden ja ryhmien ohjenuorana laadunkehittämistyössä.

Laatutyön toimintatavat: opettajien, johdon ja muun henkilökunnan toiminta, joka tähtää opetuksen ja oppimisen laadun varmistukseen ja parantamiseen.

Laatuohjelman tukitoiminnot: esimerkiksi rahoitetut erityisprojektit tai yksiköt, jotka tukevat opettajien ja heidän työnsä kehittämistä

Arvot ja kannustimet: laadunkehittämistä edistävä ilmapiiri, jossa sekä sisäiset että ulkoiset kannustimet ovat käytössä.

\section{JATKUVAAN SISÄISEEN ARVIOINTIIN}

Kuten eräissä muissa maissa, Suomessa ei olla lähdetty rakentamaan jatkuvan ulkoisen arvioinnin järjestelmää korkeakoulutukselle (Hämäläinen, 1997). Isossa-Britanniassa, missä korkeakoulujen arviointi on tiukasti yhteydessä niiden rahoitukseen, on harkittu, että alettaisiin arvioida ensisijaisesti laadunvarmistuksen toimivuutta. Jos tässä arvioinnissa todetaan, että korkeakoululla on vahvat sisäiset laadunvarmistus- ja kehittämismenettelyt, niissä suoritetaan kokonaisarviointeja harvemmin (Tysome, 1998). 
Ulkoisen tahon ohjaamat ja rahoittamat arvioinnit ovat usein melko suuria projekteja, jotka kuluttavat organisaation voimavaroja. Niistä olisi seurattava muutakin kuin sen hetkisen tilanteen arvio ja yksittäinen kehittämisehdotus. Harveyn (1997) ajatuksen mukaan niistä pitäisi poikia jatkuvan sisäisen arvioinnin työkaluja. Ulkoisen arvioinnin pitäisi siis tukea ja edistää korkeakoulun SISÄISEN ARVIOINNIN JA KEHITTÄMISEN traditiota. Jatkuvan itsearvioinnin käyttöönotosta on viitteitä pilottivaiheeseen osallistuneilla ammattikorkeakouluilla (Kostamo, 1998).

Kevään kuluessa laatutyön arvioinnin ovat läpikäyneet Mikkelin, Pohjois-Karjalan ja Seinäjoen ammattikorkeakoulut. Arviointitulokset julkaistaan Arviointineuvoston julkaisusarjassa toukokuussa. Mikkelin ja Pohjois-Karjalan ammattikorkeakoulut käyttivät itsearvioinnissaan sovellettua Suomen laatupalkintomallia. Arvioinnissa korostui ammattikorkeakoulun kokonaistoiminnan näkökulma. Seinäjoen ammattikorkeakoulun arviointi taas tarjoaa esimerkin opetustoimintaan liittyvän laatutyön arvioinnista.

\section{Lähteet}

Arviointityöryhmän esitys ammattikorkeakoulujen laatutyön arviointia varten. Muistio 1.10.1997, työryhmä: Forsberg, J., Kantola, J., Koskensilta, K. ja Laitinen, M-L

DILL, D. (1998) Professional Responsibility and Quality Assurance: the Role of Academic Audits. Lifelong Learning in Europe 2/1998, 68-75.

HARVEY, L. (1997) External Quality Monitoring in the Market Place. Tertiary Education and Management 3/1 1997, 25-35.

Higher Education Policy in Finland. Ministry of Education. 1998

HÄMÄLÄINEN, K. (1997) Arviointijärjestelmien hyödyllisyydestä. Yliopistotieto 4/97, 56-60.

KOSTAMO, T. (1998) Laatutyö ammattikorkeakoulussa, teoksessa Parjanen, M. (toim.) Oppimisen ja laadun kiasma. Tampere University Press.

LIUHANEN, A-M. (1997) Yliopistot arvioivat toimintaansa: mitä opitaan? Korkeakoulujen arviointineuvoston julkaisuja 2:1997.

MASSY, W.F. (1997) Teaching and Learning Qualityprocess Review: the Hong Kong programme,

Quality in Higher Education, 3/3,1997, 249-262.

Oppi ja laatu. Opetustoimen laadun arviointiperusteet. Efektia Oy. 1998

Pilot Audit of Quality Work in Kajaani, Turku, Lahti and Häme Polytechnics. Publications of Higher
Education Evaluation Council 7:1998

RAIVOLA, R. (1998) Miten varmistua professionaalien työn laadusta? Teoksessa Parjanen, M. (toim.) Oppimisen ja laadun kiasma. Tampere University Press.

SILÉN, T. (1998) Laatujohtaminen - Menetelmiä kilpailukyvyn vahvistamiseksi. WSOY.

SQUIRES, G. (1998) Arvioidaan opetusta, parannetaan oppimista, teoksessa Hämäläinen, K. \& Moitus, S. (toim.) Laatua korkeakoulutukseen, teoriaa ja käytäntöä. Korkeakoulujen arviointineuvoston julkaisuja 6:1998.

SYRJÄNEN, E. (1997) Arvioinnin avulla laatua kouluihin - markkinahumua vai koulurealismia. Tampereen yliopiston opettajankoulutuslaitoksen julkaisuja A11/1997.

VIRTANEN, A. (toim.) Armottomat ammattikorkeakoulut. Matkalla kehittyneisiin arviointijärjestelmiin. Korkeakoulujen arviointineuvoston julkaisuja 1:1997.

TYSOME, T. (1998) Quality: How it All Fits Together, The Times Higher Education Supplement, June 5, $1998,6$.

ÖSTLING, M. (1998) Self-Evaluation for Audit: a Tool for Institutional Improvement?

International Network for Quality Assurance Agencies in Higher Education, 15, January 1998, 7-9.

\section{Viitteet}

1. Eija Syrjäläisen raportissa esitellään helsinkiläisten opettajien ja rehtoreiden kokemuksia Oppi ja laatu - arviointikoulutuksesta.

Anna-Maija Liuhasen toimittamassa raportissa yliopistojen ja muiden tiedekorkeakoulujen edustajat esittelevät omaa arviointitoimintaansa.

2. Asiakkailla tarkoitetaan niitä tahoja, joita varten ammattikorkeakoulu on olemassa ja joiden tarpeita se toiminnallaan tyydyttää. Opiskelijaa ei kuitenkaan nähdä pelkästään asiakkaana, vaan myös aktiivisena toimijana. Sidosryhmiä ovat ne tahot, joiden tarpeet ja näkemykset on otettava huomioon tavoitteiden asettelussa. Keskeinen sidosryhmä on työelämä.

Artikkeli saapui toimitukseen 10.11.1998. Toimituskunta teki siitä julkaisupäätöksen 25.3.1999. 